\title{
Improved understanding of groundwater flow in complex superficial deposits using three-dimensional geological-framework and groundwater models: an example from Glasgow, Scotland (UK)
}

\author{
R. J. Turner • M. M. Mansour • R. Dearden • \\ B. É. Ó Dochartaigh • A. G. Hughes
}

\begin{abstract}
Groundwater models are useful in improving knowledge of groundwater flow processes, both for testing existing hypotheses of how specific systems behave and predicting the response to various environmental stresses. The recent advent of highly detailed three-dimensional (3D) geological-framework models provides the most accurate representation of the subsurface. This type of modelling has been used to develop conceptual understanding of groundwater in the complex Quaternary deposits of Glasgow, Scotland (UK). Delineating the 3D geometry of the lithostratigraphical units has allowed the most detailed conceptualisation of the likely groundwater flow regime yet attempted for these superficial deposits. Recharge and groundwater flow models have been developed in order to test this conceptual understanding. Results indicate that the direction of groundwater flow is predominantly convergent through the permeable, relatively thick Quaternary deposits of the Clyde valley towards the River Clyde, which runs through Glasgow, with some indication of down-valley flow. A separate nearby system with thick and potentially permeable Quaternary deposits, the Proto-Kelvin Valley, may also be a significant conveyor of groundwater towards the River Clyde, although the absence of local data makes any conclusions conjectural. To improve the robustness of the current model there is a need for an overall increase in good quality groundwater-level data, particularly outside
\end{abstract}

Received: 6 June 2014 / Accepted: 22 October 2014

Published online: 9 December 2014

(C) The Author(s) 2014. This article is published with open access at Springerlink.com

R. J. Turner · B. É. Ó Dochartaigh

British Geological Survey,

Murchison House, West Mains Road, Edinburgh, EH9 3LA, UK

M. M. Mansour · R. Dearden · A. G. Hughes

British Geological Survey,

Environmental Science Centre, Nicker Hill, Keyworth, Nottingham, NG12 5GG, UK

M. M. Mansour (

British Geological Survey, Keyworth, Nottingham NG12 5GG, UK e-mail: majm@bgs.ac.uk

Tel.: +44 1159363509 central Glasgow. A prototype groundwater-monitoring network for part of Glasgow is an encouraging development in this regard. This would allow the development of a time-variant groundwater model which could be used to study future modelling scenarios.

Keywords Conceptual modelling · 3D geological modelling · Superficial deposits · Urban groundwater . UK

\section{Introduction}

Urban regeneration in the UK aims to facilitate land recycling, sustainable development and effective land and water resources management to tackle issues associated with industrial decline. In the Clyde corridor, which is Scotland's national regeneration priority, the British Geological Survey (BGS) works with local stakeholders to address many issues associated with regenerating urban areas. These include assessing complex ground conditions, remediation of pollutants from the city's industrial legacy, assessing the role that groundwater plays in urban flooding, and considering the impact of the installation of sustainable drainage systems (SuDS) on groundwater.

Despite the complexity of urban groundwater processes, e.g. Lerner (2002), groundwater models are a useful tool for investigating issues such as these, and several studies have developed numerical simulations of groundwater in urban areas. For example, Epting et al. (2008) undertook groundwater modelling to predict local groundwater level impacts as a result of a proposed road tunnel construction project in the city of Basel, Switzerland. A regional-scale groundwater model was constructed for Cardiff in Wales (UK) by Heathcote et al. (2004) to predict the impact of the proposed Cardiff Bay barrage on groundwater levels. Gobel et al. (2004) examined the impact of changing recharge distribution due to urbanisation on the water table over a $12-\mathrm{km}^{2}$ area of North Recklinghausen, North Rhine-Westphalia, Germany. A numerical groundwater model has been previously developed for a small area $\left(370 \mathrm{~km}^{2}\right)$ of Glasgow (Merritt et al. 2009; Campbell et al. 2010), but numerical modelling of 
groundwater in Glasgow's Quaternary deposits at a city scale had not previously been attempted. This modelling study helps to improve understanding of the urban groundwater system, and allows for investigation of the potential future system behaviour by predicting the response to various environmental stresses. To achieve this, it was necessary to build conceptual understanding of the hydrogeology of the complex Quaternary deposits beneath Glasgow, which was hitherto poorly understood.

Conceptualisation of aquifer systems has traditionally relied upon two-dimensional (2D) geological maps and cross-sections in order to develop an understanding of groundwater flow in three dimensions. This process typically involves significant simplification of geological structure and a potential reduction in understanding of the hydrogeological system (Wycisk et al. 2009). The recent development of three-dimensional (3D) geological models provides opportunities for improving the conceptualisation of groundwater systems, and such models have proved especially helpful in interpreting the complex geology often found in Quaternary aquifer systems (Burke et al. 2010).

An early example of the appreciation of the use of 3D conceptual models is described in Martin and Frind (1998) where borehole capture zones were delineated in a complex glacial aquifer system in Waterloo, Canada. They used borehole data to generate a large number of interconnecting geological sections, and then interpolated between the sections to generate laterally complete elevation and hydraulic conductivity surfaces. This is very similar to the process used to generate $3 \mathrm{D}$ geological models in this report and was an early indication of the power of this approach. The geological mapping and the development of regional geological models within the Oak Ridges Moraine-Greater Toronto Area (Sharpe et al. 1999) use the same approach.

Since the wider deployment of 3D geological modelling software, the use of 3D geology models has become an established technique for portraying geological information and this has assisted the understanding of complex geological settings (Berg et al. 2011). The use of 3D geological models in the conceptualisation of hydrogeological systems has also become increasingly commonplace as shown in Table 1. The British Geological Survey is developing methods to directly import geological models into groundwater flow model software (Kessler et al. 2007; Royse et al. 2010).

To contribute to the regeneration activities in Glasgow, BGS has, as part of its multi-disciplinary Clyde Urban Super Project (CUSP), developed a 3D geological model with almost complete coverage of the wider Glasgow conurbation. The aim of this report is to describe the further development of a conceptual model of Glasgow's shallow Quaternary groundwater system (first described by Merritt et al. 2009) using data from these models. It demonstrates the power of using information acquired from 3D geological models by contrasting the new conceptual groundwater model to an earlier conceptual model developed based on 2D geological maps. Finally, groundwater flow processes identified in the new conceptual model were tested using a numerical groundwater flow model.

\section{Study area}

Glasgow, in west central Scotland, is the country's largest city and covers an area of approximately $400 \mathrm{~km}^{2}$, located at the mouth of the River Clyde in the north-west of the $3,100 \mathrm{~km}^{2}$ Clyde catchment (Fig. 1). The catchment is primarily upland, with urbanisation in the lowlands to the north-west. With the exception of urban areas, land use within the Clyde catchment is dominantly moorland, grassland and arable farming, with significant forestry and woodland in the centre of the catchment. It is drained by the River Clyde, and significant tributaries include the River Kelvin and the White Cart and Black Cart Waters. The climate is temperate maritime with an average precipitation of $1,100 \mathrm{~mm}$ year $^{-1}$. Potential evaporation rates are in the order of $500 \mathrm{~mm}$ year $^{-1}$ (Met Office 2014).

The detailed study area for which a numerical groundwater flow model of Glasgow has been developed is located in the north-west of the Clyde catchment, in a wide, gently undulating plain surrounded by hills, with elevations ranging from about 0 to $350 \mathrm{~m}$ above Ordnance Datum (AOD). The flow model area (Fig. 1) is approximately $600 \mathrm{~km}^{2}$ and is mostly urban, encompassing most of the Glasgow conurbation with some of the surrounding rural area. Land use includes residential, commercial and industrial, as well as open parkland and moorland.

The bedrock geology of the Clyde catchment is dominated by Carboniferous sedimentary rocks, including the Scottish Coal Measures Group, the Strathclyde Group and the Clackmannan Group. These consist mostly of repeating cyclical sedimentary sequences of sandstone, siltstone and mudstone, with thin coal bands. Contemporaneous igneous rocks include basaltic lava flows of the Clyde Plateau Volcanic Formation that form the terraced plateau of the Campsie Fells and the escarpments of the Kilpatrick Hills, which were created by large-scale volcanism during the early Carboniferous. Later intrusive igneous rocks date from the late Carboniferous and early Permian and mostly take the form of doleritic sills and dykes. Small outcrops of volcanic clastic sedimentary rocks also occur.

The Quaternary deposits across the Clyde catchment were deposited during and following the last glacial maximum about 18,000 years ago. Most widespread is diamicton interpreted as till, which in Glasgow comprises mainly the Wilderness Till Formation. This is an often poorly sorted deposit of pebbles, cobbles and boulders in a matrix of silt, sand and clay, which is often heavily compacted and is thickest in the valleys and thin or absent on high ground. Overlying the till in many areas, and deposited by melt waters as the ice sheet retreated, are glaciofluvial sands and gravels, deltaic sands and gravels and glaciolacustrine silts and clays. The major geological units identified in the Clyde Valley are the Gourock Sand, 
Table 1 Previous use of 3D geological models in the conceptualisation of hydrogeological systems

\begin{tabular}{ll}
\hline Model application and type & Reference \\
\hline An EarthVision 3D volume model was used to characterise hydrogeological units in a complex & Artimo et al. (2003) \\
Quaternary esker aquifer & Cherry et al. 2011 \\
The Victorian Department of Primary Industries, Australia, developed regional-scale 3D models to & \\
understand the distribution and history of mineral deposits, as well as energy and water resources & Robins et al. (2005) \\
3D geological visualisation tools were used to facilitate the development of robust and defensible & Spottke et al. (2005) \\
conceptual groundwater models and were found to be cost effective & Russell et al. (2011a and 2011b) \\
Geological model data were used in a MODFLOW model of a geologically complex region & \\
of north-western Switzerland near Basel & Thomsen (2011) \\
Key Canadian aquifers were modelled by the Geological Survey of Canada, resulting in increased & White et al. (2013) \\
understanding of groundwater resources, by integrating approaches including remote sensing, & \\
geophysics, 3D geological models, and 3D numerical hydrogeological models into basin & Wycisk et al. (2009) \\
analyses & \\
High-resolution airborne geophysical data were integrated into local 3D hydrogeological models & \\
Three-dimensional models were developed to represent the distributions of key sediments and static & groundwater level in the lower Wairau Plain, New Zealand \\
High-resolution 3D modelling was used to characterise the complex geological environment of the & Bitterfeld/Wolfen megasite in the eastern part of Germany \\
\hline
\end{tabular}

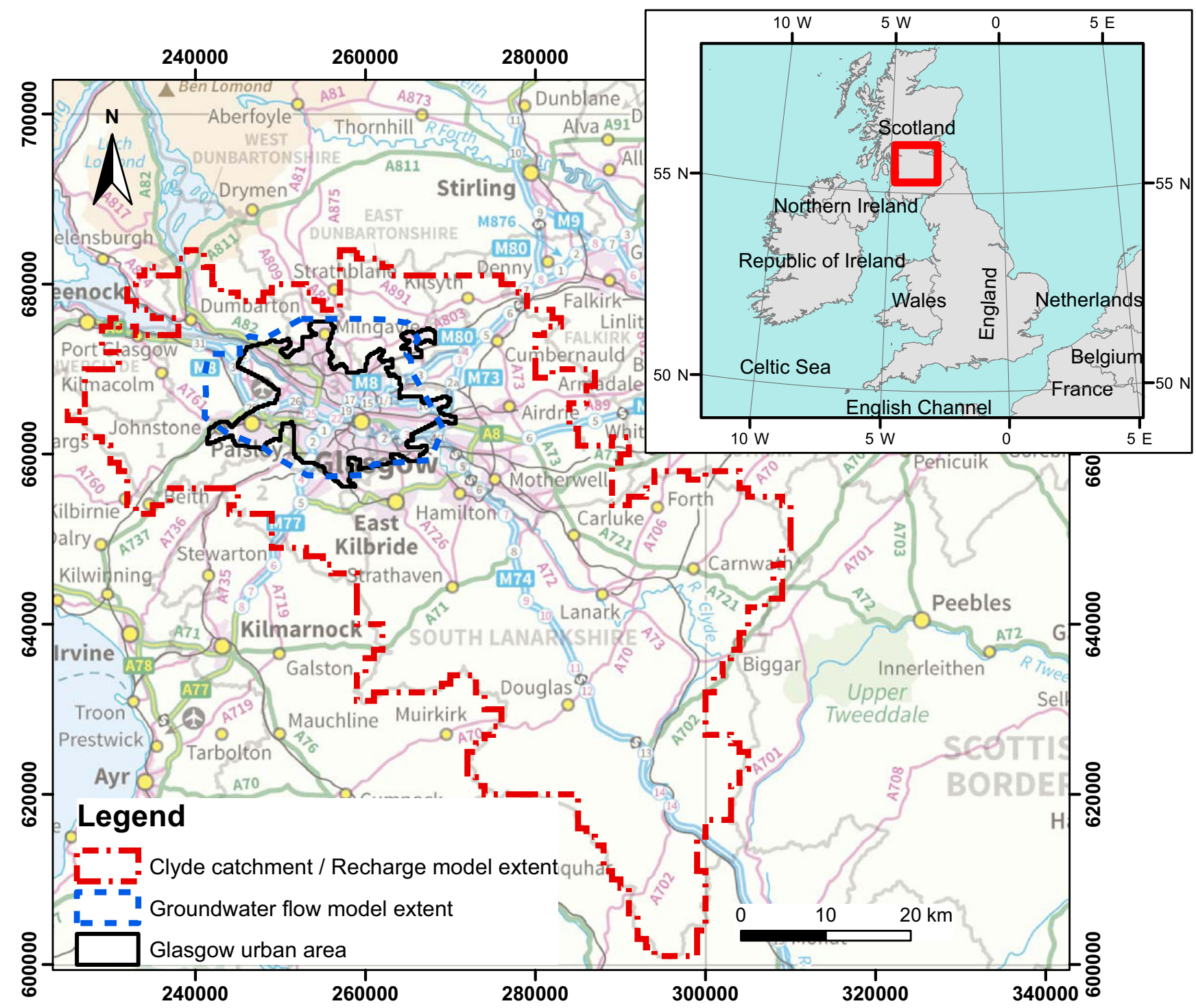

Fig. 1 Groundwater flow model area depicted (blue dashed line) in relation to the Glasgow urban area (black line) and River Clyde catchment (red dashed line), Scotland (UK) "Contains Ordnance Survey data (C) Crown Copyright and database rights 2014. Licence number 100021290" 
Bridgton Sand and Paisley Clay members (Figs. 2 and 3). A substantial buried valley, or tunnel valley, is present beneath the flood plain of the River Kelvin, to the north of Glasgow. This west-south-west to east-north-east trending feature is unrelated to that of the present River Kelvin catchment, and can be traced for approximately $60 \mathrm{~km}$ to the northeast. It is incised in bedrock and is infilled with thick (locally greater than $100 \mathrm{~m}$ ) glaciofluvial sand and gravel including the Cadder Sand and Gravel Formation and the overlying Ross Sand Member, which are both underlain and overlain by variably thick till (Campbell et al. 2010). A summary of the lithology of these geological units is shown in Table 2.

Following ice retreat, when sea levels were higher than today, extensive raised marine deposits of sand, gravel, clays and silts were laid down in low-lying areas near the lower reaches of the present course of the River Clyde. After sea levels fell to present-day levels, alluvium was deposited adjacent to the River Clyde and its major tributaries. Anthropogenic deposits of variable lithological character are also present over much of Glasgow.

Today there is little groundwater abstraction in the Glasgow area. This is largely because of the plentiful availability of surface water in the region, but also because of perceived and/or actual poor quality of groundwater, either due to urban contamination or to the impacts of former coal mining in bedrock. There has been little or no exploration of groundwater resources in the potentially productive Quaternary aquifer formed by the thick sand and gravel deposits of the Proto-Kelvin Valley. Historically, groundwater was widely abstracted from moderately productive Carboniferous sedimentary aquifers in and around Glasgow for industrial use, including brewing. Fracture flow controls groundwater movement in these bedrock aquifers, and previous studies concluded that groundwater flow paths can be deep and long, with Glasgow the focal point for much of the groundwater discharge converging from the east, north-east and southeast (Hall et al. 1998). In the adjacent volcanic rocks, groundwater flow is also controlled by fracture flow, but these rocks form low productivity aquifers in which groundwater flow paths are likely to be predominantly discharging to local rivers.

The Carboniferous sedimentary rocks beneath Glasgow and surrounding areas were extensively exploited for mining for coal and other minerals, particularly through the 19th century and first half of the 20th century, which also saw extensive abstraction for mine dewatering purposes. Mine dewatering gradually decreased up to the late 1980 s as mines were abandoned and allowed to flood. Although there are no

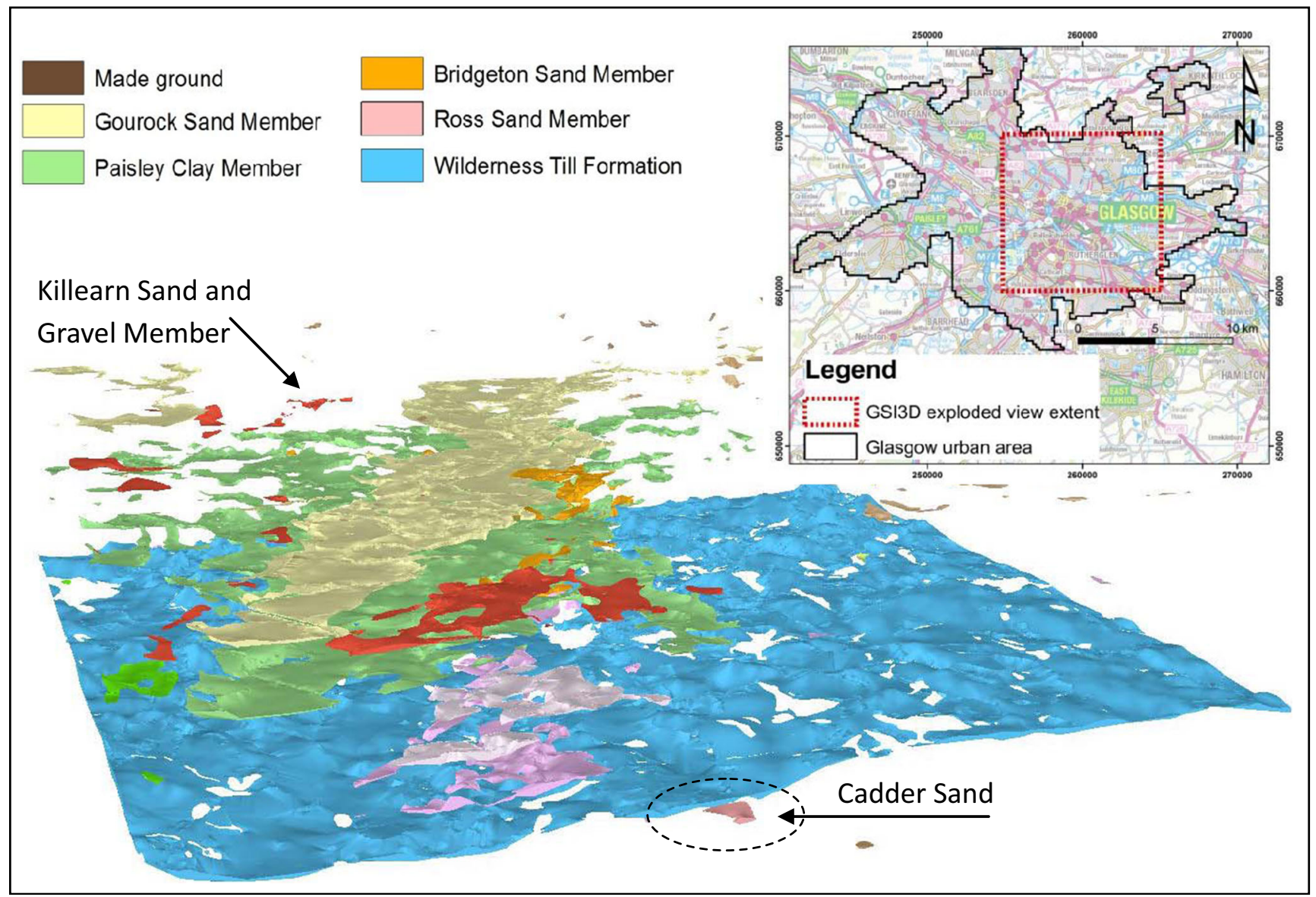

Fig. 2 Three-dimensional view of the superficial deposits using the GSI3D software "NEXTMap Britain elevation data from Intermap Technologies" 

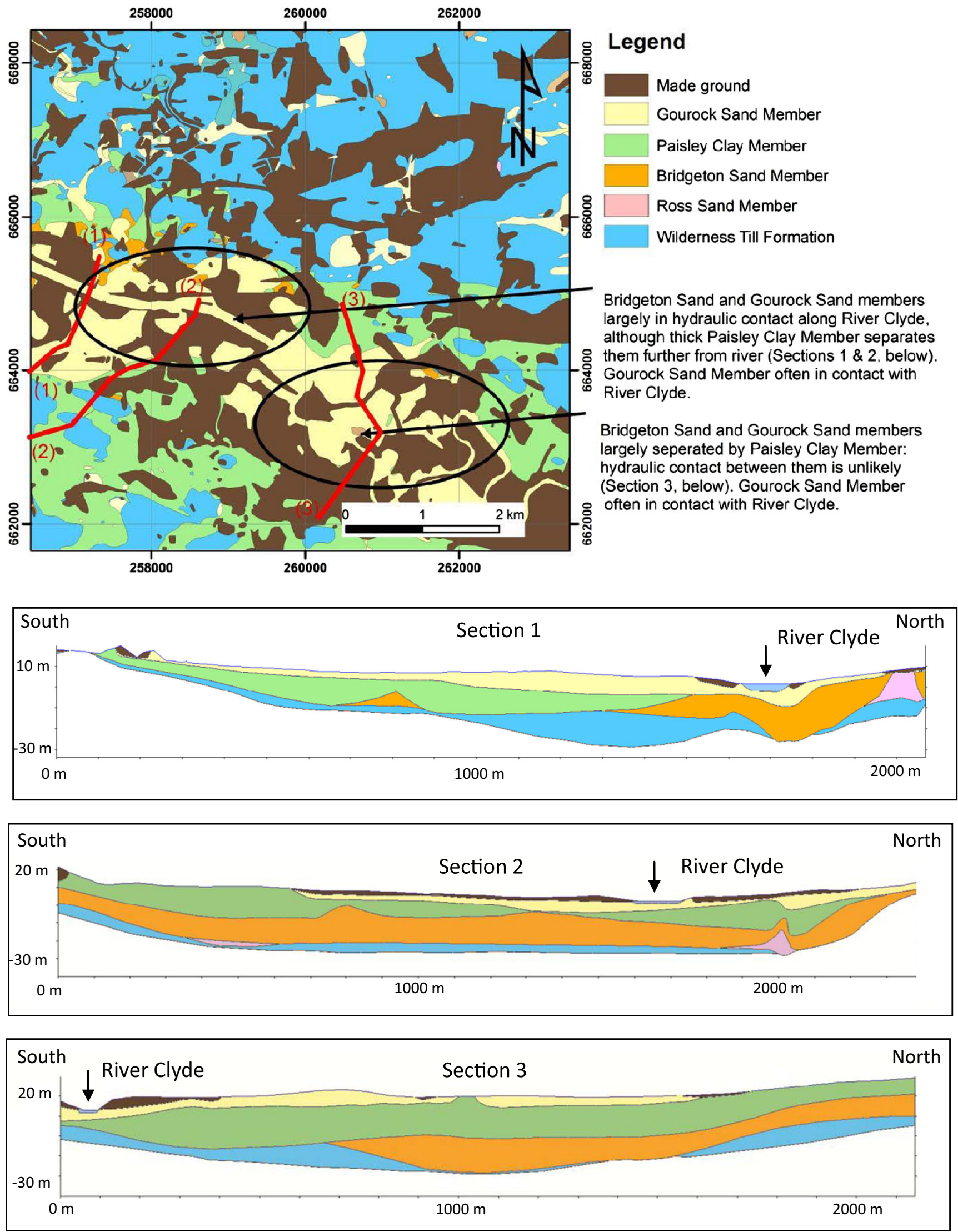

Fig. 3 Conceptual model development for Clyde Valley Aquifer, showing cross sections exported from the GSI3D model of superficial deposits along the (red) lines drawn on the map 
Table 2 Summary of lithological analysis of geological units

\begin{tabular}{llll}
\hline Aquifer & Geological unit & Lithological analysis & \\
\cline { 2 - 4 } & & Percentage of sandy and gravelly deposits & Percentage of clayey deposits \\
\hline Clyde Valley & Gourock Sand Member & $76 \%$ & $24 \%$ \\
& Bridgeton Sand Member & $100 \%$ & $0 \%$ \\
Proto-Kelvin Valley & Cadder Sand and Gravel Formation & $100 \%$ & $0 \%$ \\
\multirow{2}{*}{ Non aquifer } & Ross Sand Member & $54 \%$ & $46 \%$ \\
& Paisley Clay Member & $0 \%$ & $100 \%$ \\
\hline
\end{tabular}

major reported problems caused by rising groundwater levels in Glasgow, and there is no active pumping to control the levels; a lack of modern data means that groundwater levels in the bedrock aquifers beneath the city are largely unknown (Ó Dochartaigh 2005).

Mining has led to significant changes in natural groundwater flow regimes, with former mines forming open or partially collapsed and/or infilled voids which can significantly increase natural permeability (Ó Dochartaigh 2005). Mining has also caused deterioration in groundwater quality, which was one of the main reasons for reduced groundwater abstraction in Glasgow (Hall et al. 1998).

Before the current study, the groundwater flow regime in the Quaternary deposits was poorly understood. Preliminary analysis of limited groundwater monitoring data indicated some hydraulic connection between the River Clyde and adjacent permeable Quaternary deposits, with down-valley flow paths (Bonsor et al. 2010; Campbell et al. 2010). The extensive and often thick Quaternary deposits were thought likely to exert a significant control on recharge distribution across Glasgow and the surrounding areas, as well as influencing natural surface water drainage. It is also probable that there is significant interaction between groundwater in the bedrock and superficial aquifers, though data to confirm and characterise this are lacking.

\section{Historic perspective of groundwater research in Glasgow}

In an earlier, smaller-scale groundwater modelling study in Glasgow (Merritt et al. 2009; Campbell et al. 2010), a simple conceptual groundwater model for Glasgow was developed using a combination of 2D geological maps and an early 3D geological model (GSI3D) of approximately $100 \mathrm{~km}^{2}$ area in eastern of Glasgow. Since this work was completed, 3D geological models of Glasgow, built using GSI3D for the superficial deposits, and GoCAD for the faulted bedrock, have been expanded so that that there is now almost complete coverage at high resolution of the urban area, and lower resolution coverage of the Clyde catchment. The models have also gone through several processes of revision to increase the accuracy of geological information presented, and provided an opportunity to revisit and improve the small-scale simple conceptual model of groundwater flow and expand it across the whole city of Glasgow. This work also illustrates the benefits of using 3D geological models to develop conceptual groundwater models.
GSI3D is a 3D geological framework modelling methodology that captures a geologist's conceptualisation of geological structure. It allows the geologist to interpret digital terrain models, geological maps and downhole borehole data (records from over 50,000 boreholes were coded digitally and used in the modelling of Glasgow) to create regularly spaced interconnecting cross-sections (fence diagrams). By interpolating between nodes along these cross-sections and in unit distributions, a solid model of the subsurface is created. The geological model of Glasgow extends throughout the Clyde Basin. This model allows visualisation and interpretation of the complex superficial deposits of Glasgow, and has been a key tool in improving understanding of the behaviour of the groundwater system. An example of a 3D view of part of the superficial deposits in Glasgow is shown in Fig. 2. For a detailed explanation of the GSI3D methodology see Kessler et al. (2009).

For the earlier groundwater modelling study in Glasgow, the lithostratigraphic units represented in the geological models and maps were simplified to give three hydrogeological units (Merritt et al. 2009; Campbell et al. 2010). Virtually no quantitative data on aquifer properties are available for Glasgow, and in their absence it was assumed that sand and gravel deposits have relatively high hydraulic conductivity and storage capacity, and clay-rich units much lower hydraulic conductivity and storage capacity. The upper model layer represented a nearsurface high-permeability unit, and the lower layer was subdivided into a moderate permeability unit comprised primarily of fine sands, and a low permeability unit comprised largely of silts and clays. In areas beyond the coverage of the earlier 3D geological model developed over the eastern part of Glasgow, the elevations of the two hydrogeological units were estimated by linear interpolation from selected points along the boundary of the 3D geological model, to the outer groundwater model boundary where the Quaternary deposits were assumed to decline to a minimal thickness. The resulting conceptual model was of a groundwater system made up of a single expansive superficial hydrogeological unit that was in close hydraulic connection with the River Clyde.

\section{Conceptualisation of the groundwater flow regime}

An expanded and refined 3D geological framework model of superficial deposits and depth to rockhead, covering all of Glasgow, is now available. This was also developed in 
GSI3D and includes 21 distinct lithostratigraphic units, including made ground; full details of lithostratigraphic units and model development are given in Monaghan et al. (2014). For the current study, the 3D geological framework model was used to investigate the likely hydraulic characteristics of, and connections between, different geological/lithostratigraphic units, expanding the conceptual groundwater model to cover the whole city.

As with the earlier smaller-scale groundwater model, the Quaternary geological sequence across the whole city was simplified by grouping together lithostratigraphic units in the 3D geological model and assuming they have similar hydraulic properties. As no new quantitative hydraulic aquifer property data have become available for this area since the earlier study, hydraulic properties were again estimated by reference to the dominant lithology of each lithostratigraphic unit. This was determined by an analysis of the percentage composition of each lithological type (sand, clay, etc.) in each individual lithostratigraphic unit based on lithological logs for the study area. As in the Merritt et al. (2009) study, it was assumed that sand-rich units have higher hydraulic conductivity, and are likely to contribute to the majority of groundwater flow within the Quaternary deposits, whereas the clay-rich deposits are likely to have lower hydraulic conductivity.

The internal 3D model visualisation capability of GSI3D was used in conjunction with the export of a series of approximately regularly spaced geological sections running across the hypothesised axis of groundwater flow (Fig. 3). From these, areas of likely hydraulic connectivity were identified between adjacent sandy, potentially conductive (permeable) units, and between potentially conductive units and the major surface water features, the River Clyde and River Kelvin. Areas where thick (>3 m) low-permeability (e.g. till or other clay-rich) deposits occur were identified as probable barriers to groundwater flow. In areas where potentially conductive sandy units are separated by thin $(<3 \mathrm{~m})$ till or clay units, some groundwater flow was anticipated. A map showing the thicknesses of these potentially conductive Quaternary units is shown in Fig. 4. By building up these conceptual diagrams, a better understanding of the likely behaviour of the shallow groundwater system was developed.

In the revised conceptual model, the superficial deposits in Glasgow are no longer treated as a single hydrogeological unit, but instead as two key components of the shallow groundwater system. The first comprises sandy deposits of the Gourock Sand and the Bridgeton Sand members along the River Clyde, which are assumed to be permeable, and which together have been modelled as the Clyde Valley Aquifer (Fig. 5). The Clyde Valley Aquifer is generally less than $30 \mathrm{~m}$ thick and is not overlain by significant low permeability deposits, and so is likely to accept recharge readily.

The second key component of the shallow groundwater system is the Cadder Sand and Gravel Formation (part of

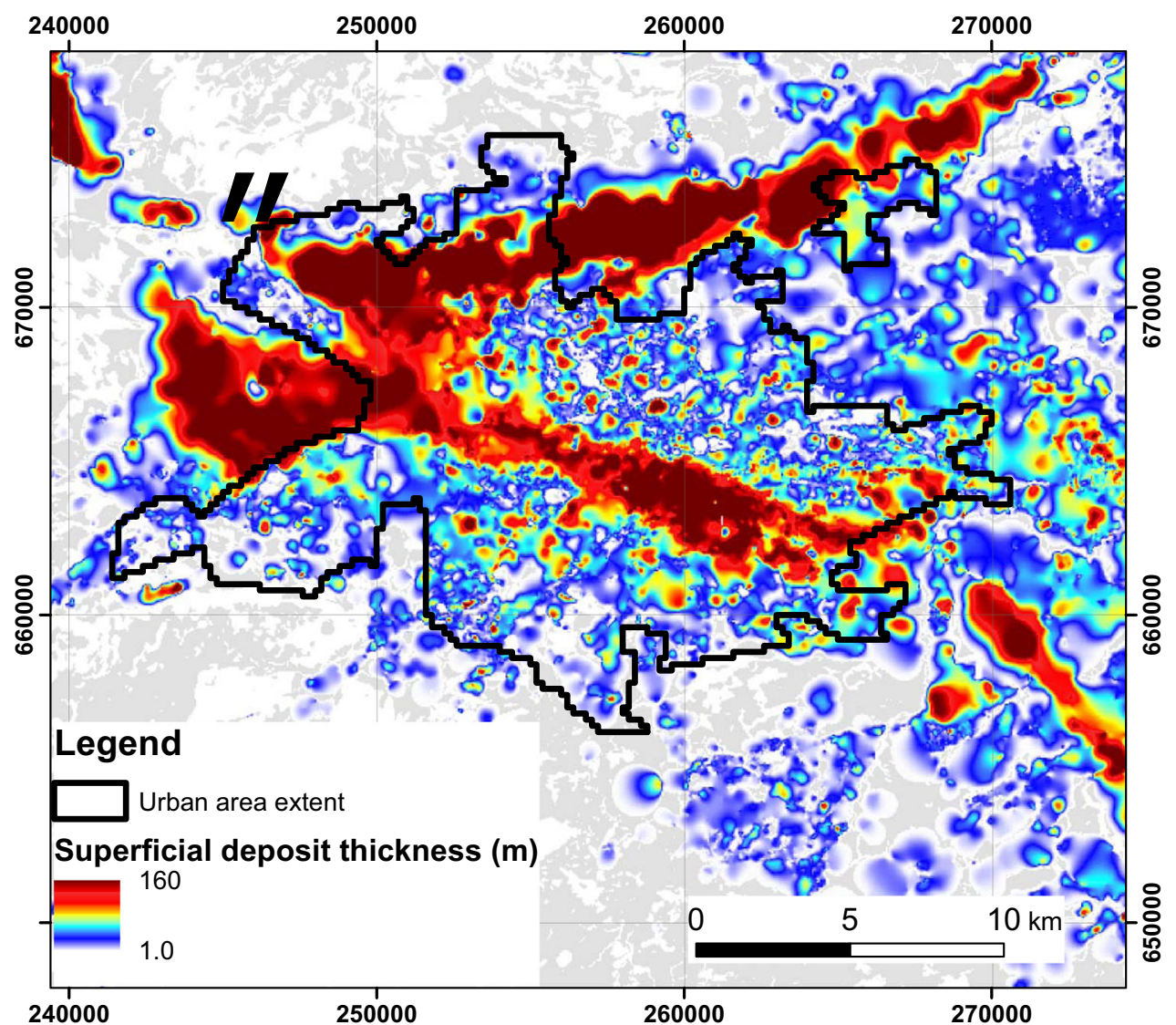

Fig. 4 Superficial deposit thickness 


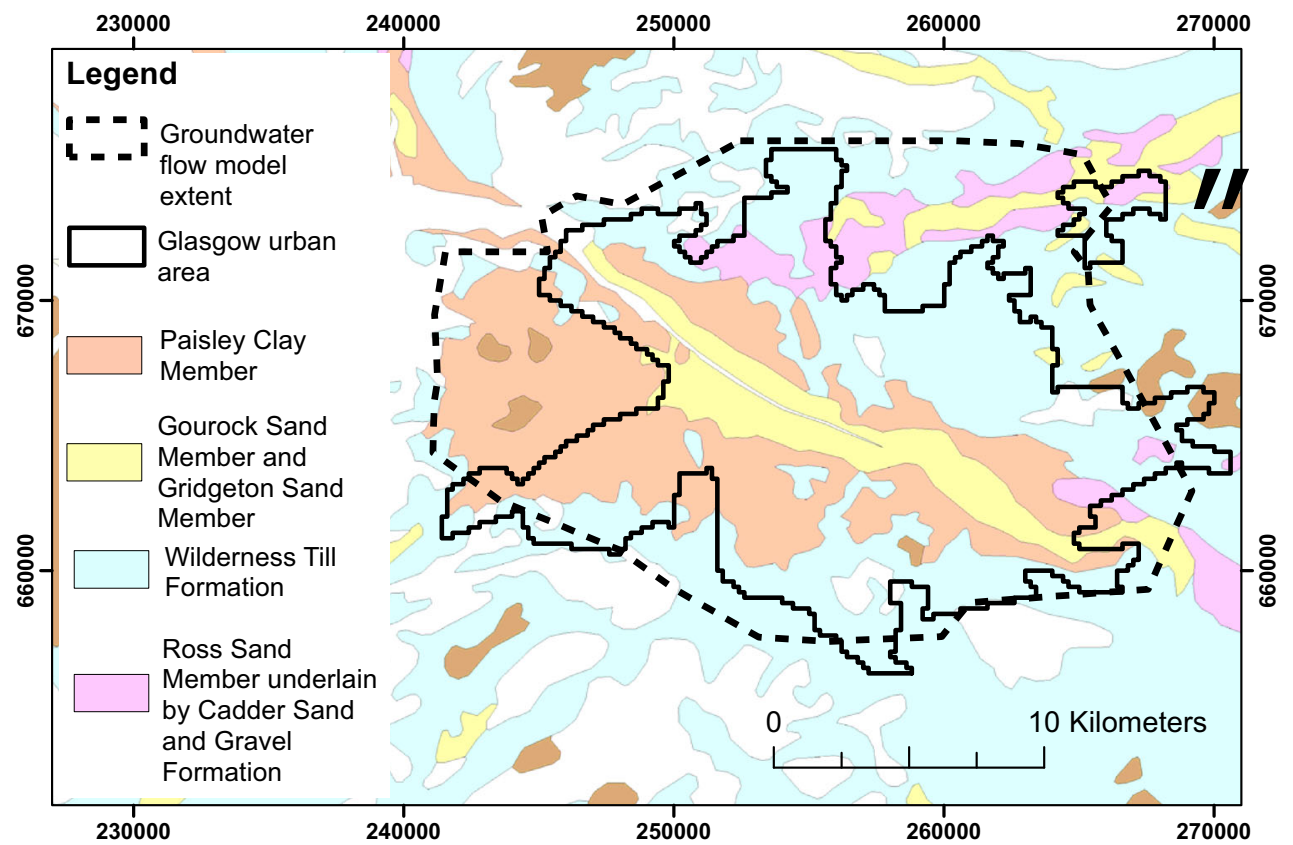

Fig. 5 Extent of the groundwater flow model area, with urban area extent and summary of Quaternary geology

which is highlighted in Fig. 2) and the overlying Ross Sand Member within the Proto-Kelvin Valley in the north of Glasgow (Fig. 5). Both lithostratigraphic units are assumed to have high permeability. The Wilderness Till Formation lies between the Cadder Sand and Gravel Formation and the Ross Sand Member in most parts of the modelled area, but is generally less than $3 \mathrm{~m}$ thick, except in the far north-east of the model, and it was therefore assumed not to form a complete barrier to groundwater flow. The Cadder Sand and Gravel Formation was assumed, therefore, to be receiving recharge through the overlying Ross Sand Member. The Cadder Sand and Gravel Formation is up to $80 \mathrm{~m}$ thick, comprising a large volume of potentially highly conductive material, and is therefore assumed that it is likely to significantly contribute to local groundwater flow, although no hydrogeological data for the formation are known within the Glasgow area. The base of the buried Proto-Kelvin Valley appears to be highly irregular, dividing the valley into a series of sub-basins. Groundwater within the valley is likely to travel westwards towards the River Clyde, where the Cadder Sand and Gravel Formation terminate. However, the interaction between the River Clyde and the groundwater within the valley is still not fully understood; and this is unlikely to be resolved without additional groundwater data.

Away from these two identified potential aquifers, Quaternary deposits are dominated by low-permeability till, over which rainfall is likely to either runoff into the river network or recharge to the underlying bedrock through till-free "windows" (e.g. Cuthbert et al. 2010). In order to model this effectively, a bedrock layer was included within the conceptual model that accepts a proportion of rainfall as recharge in these till-dominated

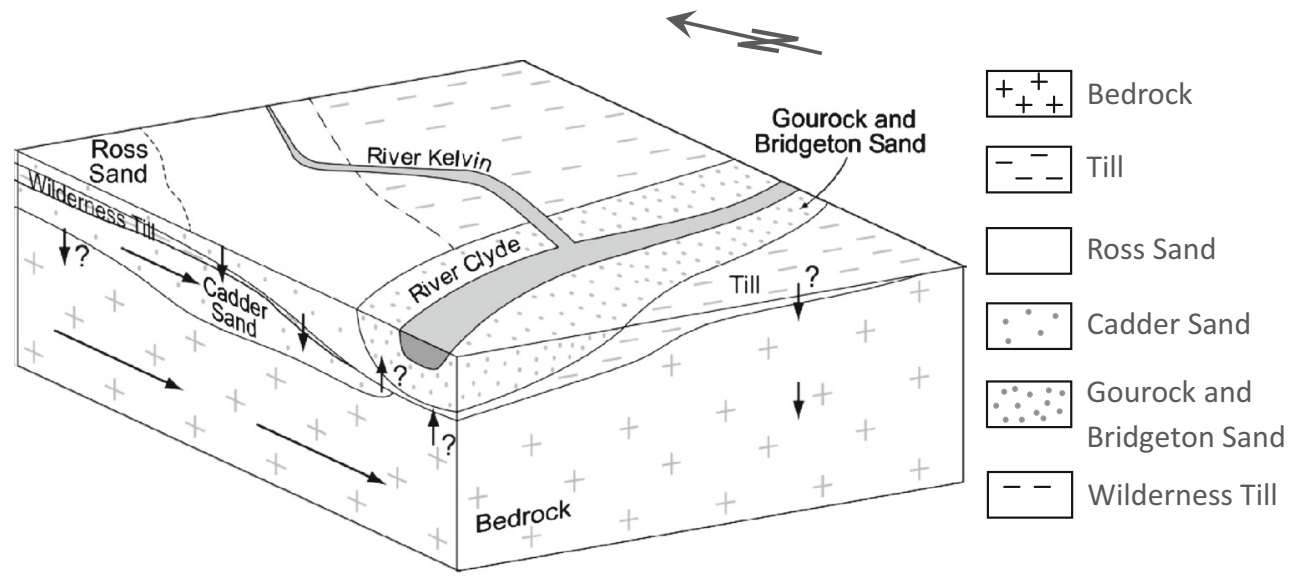

Fig. 6 Conceptual diagram of Glasgow groundwater system 
areas. The available transmissivity values are $50-100 \mathrm{~m}^{2} /$ day for the Carboniferous bedrock aquifers in the region (Ball et al. 2006), confirming that there is the potential to accept recharge and contribute to regional groundwater flow.

The refined conceptual model (Fig. 6) makes the following hypotheses:

- The Gourock Sand Member and the Bridgeton Sand Member constitute highly permeable shallow potential aquifer units, usually in hydraulic continuity with each other and with the River Clyde, and they contribute to regional groundwater flow.

- The Cadder Sand and Gravel Formation is a potentially significant aquifer unit, though its actual hydraulic nature and connection with the River Clyde are as yet unclear.

- Till is an incomplete barrier to recharge on the higher ground surrounding these two potential valley aquifers: where it is absent or less than $3 \mathrm{~m}$ thick it is assumed to allow recharge to the underlying bedrock

- The bedrock accepts recharge over higher ground through thin till and till-free windows, and transmits groundwater down-gradient towards the River Clyde, although the connection between the bedrock and Quaternary valley aquifers is unclear.

To test these hypotheses, a numerical groundwater recharge and flow model was developed to determine whether observed groundwater flows and heads could be replicated using acceptable hydraulic parameter values for the studied hydrogeological units. In particular, the aims were to investigate the response of the groundwater system to modelled recharge; and the behaviour of groundwater flow within the two sand and graveldominated valley aquifers.

\section{Testing of the conceptual model}

To test the groundwater conceptual model, a steady state numerical model was created using the flow model ZOOMQ3D (Jackson and Spink, 2004). ZOOMQ3D belongs to the suite of object oriented models which also includes the distributed recharge model ZOODRM (Hughes et al. 2008, Mansour et al. 2011) and the advective particle tracking model ZOOPT (Jackson, 2004). ZOODRM was applied to calculate distributed recharge values over the study area. ZOOMQ3D is a quasi 3D model that uses the finite difference approach to solve the partial differential equation describing the movement of water in porous medium.

The recharge model boundary encapsulates the entire surface water catchment of the River Clyde, covering an area of approximately $3,100 \mathrm{~km}^{2}$ (Fig. 1). The base grid of the model is a mesh consisting of $1,000-\mathrm{m}$ square cells. The model applies the Penman and Grindley algorithm (Penman 1948; Grindley, 1967) that calculates recharge using rainfall and potential evaporation values based on crop characteristics such as the values of root constant and the wilting point. The model also uses a recharge calculation algorithm developed specifically to account for flow processes in urban areas (Mansour et al. 2008). A single area of improved resolution was incorporated as a grid consisting of 200-m square cells overlying Glasgow to provide more detailed estimates of recharge, including accounting for urban flows such as runoff from paved surfaces and sewer leakages. Daily precipitation records for 66 rain gauges were sourced from the British Atmospheric Data Centre for the period 1961-2011. Precipitation amounts were assigned to model nodes according to Theissen polygons, which were constructed based on the spatial distribution of the rainfall gauges.

Evaporation data were sourced from the Met Office, with monthly average potential evaporation volumes for the period 1961-2009. Estimates of runoff coefficients for each flow gauge were provided by the Hydrometric Register and Statistics 1991-1995 (NERC 2003). Estimates of baseflow index (BFI) and absolute runoff were calculated, from which estimates of runoff coefficients for each flow gauge catchment were derived. A digital terrain model (DTM) (Morris and Flavin 1990) was used to derive an aspect map showing topographical gradients, which control the direction of surface water in the model. Observed river flow data were provided by the Centre for Ecology and Hydrology (CEH) from the National River Flow Archive for 35 flow gauges within the Clyde catchment, with daily average flow records for the period 1961-2009.

Calibration of the recharge model was undertaken by matching the simulated and observed overland components of river flows and modifying the runoff coefficients iteratively for specified runoff zones. Estimates of overland flow components were derived from the observed river flow volumes by baseflow separation. The ZOODRM code does not currently allow for the representation of overland storage. An initial attempt was made to incorporate this process by applying the approach presented by Mansour et al. (2011), which involves the use of a two-point moving average of the overland flow component to simulate the catchment storage. This mathematical equation divides runoff calculated at a certain time step into a specified number of parts (in this case two) and uses these parts to reproduce the total overland flow at a gauging station at the current and subsequent time steps. However, this approach did not improve the match between the observed and simulated overland flows. This may be because overland flows are rapid in the Clyde catchment and so rainfall reaches gauging stations within a single day, which is the time step used within the recharge model. It also proved difficult to replicate observed surface runoff using geologybased zones, because of the high spatial variability of the geology and the resultant runoff zones. A simpler approach was used that broadly reflects the catchment topography. This consists of dividing the study area into four discrete areas and allocating each area a set of runoff coefficients. This simple approach was sufficient to achieve satisfactory agreement between the observed and simulated overland flow time series. 
The spatially distributed long-term average (LTA) recharge values estimated over the simulation period vary between 0.17 and $1.6 \mathrm{~mm}$ day $^{-1}$ with an average value of $0.75 \mathrm{~mm}$ day $^{-1}$. These distributed LTA recharge values were used by the flow model ZOOMQ3D for a selected number of time steps until steady-state conditions were reached. The flow model grid is a uniform $200 \mathrm{~m} \times 200 \mathrm{~m}$ mesh and covers the entire Glasgow conurbation, an approximate area of $400 \mathrm{~km}^{2}$. No major groundwater abstractions are known to occur within the model area, and none have been included within the simulation. Inputs are only recharge, and groundwater discharge occurs only into the river system. The hydrostratigraphic units are represented by two numerical layers (Fig. 7). The upper layer represents the Quaternary deposits and is divided into two zones; the lower layer represents bedrock and is homogeneous across the model. The first zone in the upper layer is assigned a high permeability, representing the most significant Quaternary units in terms of aquifer hydraulic conductivity, which are the predominantly sand and gravel deposits of the Gourock and Bridgeton Sand members, the Cadder Sand and Gravel Formation and Ross Sand Member. Although the Cadder Sand and Gravel Formation extend to a significant depth below ground surface (Fig. 6), the whole of this formation is included in the upper layer to reduce complexity in the numerical model. This is acceptable because, as already discussed, it is assumed: that there is active recharge to the formation through the generally thin overlying till or through till 'windows'; that there is limited interaction between the formation and with the adjacent low permeability zone; and that there is vertical hydraulic connection between the formation and the underlying bedrock. However, hydraulic interaction between groundwater in the deeply buried Cadder Sand and Gravel Formation and rivers flowing over these areas has been eliminated by setting the values of the parameters controlling the river-aquifer interaction in these areas to zero. The second zone in the upper layer is assigned a lower permeability to represent glacial till, which surrounds the two potential valley aquifers on higher ground away from the rivers (Fig. 5). This zone incorporates an increased vertical conductance term to allow the almost instantaneous transfer of recharge through thin till and/or

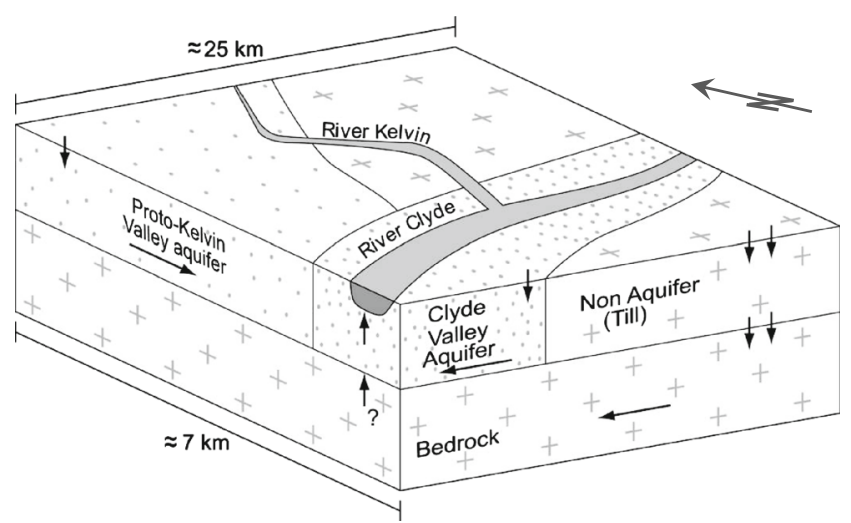

Fig. 7 Conceptual 3D scheme of the numerical model setup (legend as for Fig. 6)

Hydrogeology Journal (2015) 23: 493-506 'windows' in the till to the lower model layer, which represents bedrock.

The thickness of the upper layer of the model is derived from the NextMap (Britain elevation data Intermap Technologies) 25-m resolution DTM elevation and rockhead elevation data as defined in the Glasgow 3D geological model. This layer thickness is used to define the elevation of the upper surface of the model and the elevation of the base of the upper layer/top of the lower layer. Ground surface and rockhead elevation data were available from the 3D geological model for the vast majority of the groundwater flow model area, with the exception of the Paisley area in the west of Glasgow. In this area, ground-surface elevation was taken from a 5-m resolution NextMap DTM and the elevation of the rockhead was assumed to be located at a fixed depth from the ground. The thickness of the lower bedrock layer was assumed to be a constant and equal to $100 \mathrm{~m}$ everywhere in the model.

To the north, west and south, the boundary of the flow model is approximately coincident with the edge of the Carboniferous sedimentary Strathclyde and Clackmannan groups, where they border volcanic rocks of the Clyde Plateau Volcanic Formation. The volcanic rocks have significantly lower permeability than the sedimentary bedrock, such that this is assumed to represent a no flow boundary. To the east, the Carboniferous sedimentary bedrock extends beyond the extent of the flow model area and so it was necessary to estimate the potential inflow of water across the model boundary into the model. By assuming a constant thickness of $100 \mathrm{~m}$, a hydraulic gradient based upon observed groundwater level data, and a hydraulic conductivity of $1 \mathrm{~m} \mathrm{day}^{-1}$, groundwater inflow across the eastern boundary was estimated to account for less than $10 \%$ of total recharge over the flow model area. The majority of this inflow is expected to discharge to the River Clyde and the remaining flow is expected to have a smaller impact on groundwater heads than the acceptable error in the simulated heads. Based on this, inputs through the eastern boundary were assumed to be insignificant and it was also represented in the model as a no flow boundary.

Rivers were delineated from available topographical maps. River stage was assumed to be 1-m below ground surface as taken from a series of 25-m resolution NextMap DTMs extracted from the GSI3D models of superficial deposits and rockhead for Glasgow. Riverbed elevations for the Clyde were initially set at $-1 \mathrm{~m}$ AOD at the western end of the model and linearly increased to an elevation of $2 \mathrm{~m}$ below ground level based upon available DTM elevations at the east of the model. However, this failed to replicate accurately the accretion profile for the river and so instead riverbed elevations were defined based upon the minimum ground level recorded from a 100-m resolution NextMap DTM map at the corresponding location. A second order polynomial expression was fitted to the new bed elevations to smooth out the gradient of the riverbed and create a more accurate representation of the river profile within the model. River widths were estimated from Google Maps and riverbed conductivity was derived through model calibration. 

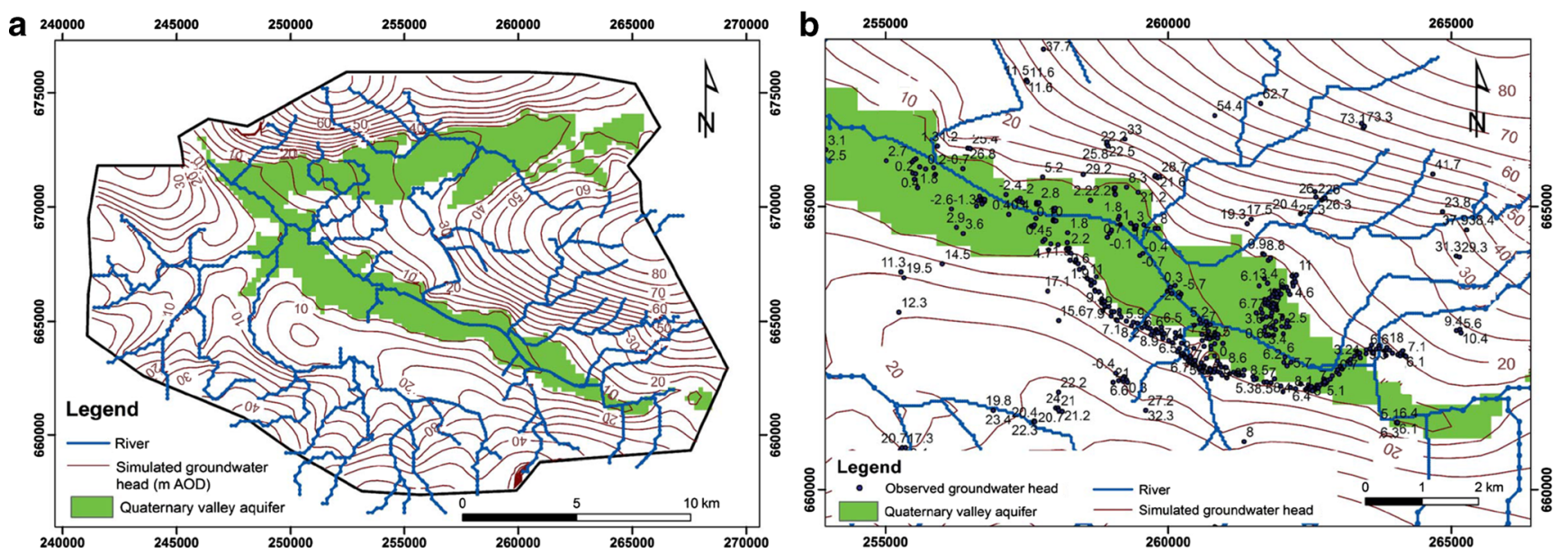

Fig. 8 a Final modelled groundwater contours, b Comparison between simulated and observed groundwater heads over the Clyde Valley Aquifer. Note that part b is an enlargement of part of a "Contains Ordnance Survey data C Crown Copyright and database rights 2014"

\section{Results}

Simulated groundwater levels at steady-state conditions were compared to observed groundwater level data from 141 boreholes. The observed groundwater level data are mostly located in central and eastern Glasgow, and most date from a period between 2007 and 2009 (data from 15 boreholes date from the period 2003-2005). They represent groundwater levels in a number of different Quaternary units, including in some cases those not explicitly defined as aquifers within the model, and also occasionally the underlying bedrock, and although best efforts were made to define the relevant geological unit for each groundwater level observation, it was not always possible to identify the geological unit. Because of the heterogeneity of Glasgow's Quaternary geology, many of the dominantly low permeability, and therefore largely non-aquifer, clay- and siltdominated units contain pockets of higher permeability sands and gravels. In some cases these may form small, discontinuous and/or perched aquifers; in other cases they may be in hydraulic continuity with nearby more widely permeable units. Although the observed groundwater level data will not always directly represent the modelled aquifer units, they are therefore likely to be largely representative at the scale of the model.

Model calibration was achieved by varying the hydraulic conductivity values of the different layers and the riverbed conductance values within sensible limits until satisfactory agreement between observed and simulated groundwater head contour lines was realised.

The final groundwater head contours derived from the calibrated flow model are shown in Fig. 8a. There is relatively good agreement between the observed groundwater level data and the simulated ones particularly within the Clyde Valley Aquifer as illustrated in both Figs. 8b and 9. Simulated groundwater levels are within approximately $1-2 \mathrm{~m}$ of the majority of observed groundwater levels and indicate the same trends in the direction of groundwater movement (Fig. 8a). To produce these simulated groundwater levels, the horizontal hydraulic conductivity value for the valley aquifer zones in the upper model layer was set to $100 \mathrm{~m}^{\text {day }}{ }^{-1}$; for the lowpermeability till zone in the upper layer to $0.1 \mathrm{~m}^{\text {day }}{ }^{-1}$; and for the lower bedrock layer to $1 \mathrm{~m} \mathrm{day}^{-1}$ (Table 3). The vertical hydraulic conductivity values are assumed to be one tenth the horizontal hydraulic conductivity values. The high contrast between the hydraulic conductivity values in the different zones is used to test the hypotheses made by the conceptual model that the sand- and graveldominated valley deposits are conductive formations, while the bedrock is much less conductive. Numerically, these values indicate that hydraulic interaction between the Quaternary valley aquifers and the underlying bedrock is likely to be limited both horizontally and vertically. However, the model demonstrates that a 100-m-thick bedrock layer with a low hydraulic conductivity value is able to transmit modelled recharge both downstream and laterally to the Clyde Valley and Proto-Kelvin Valley aquifers, with simulated groundwater heads that are close to observed ones.

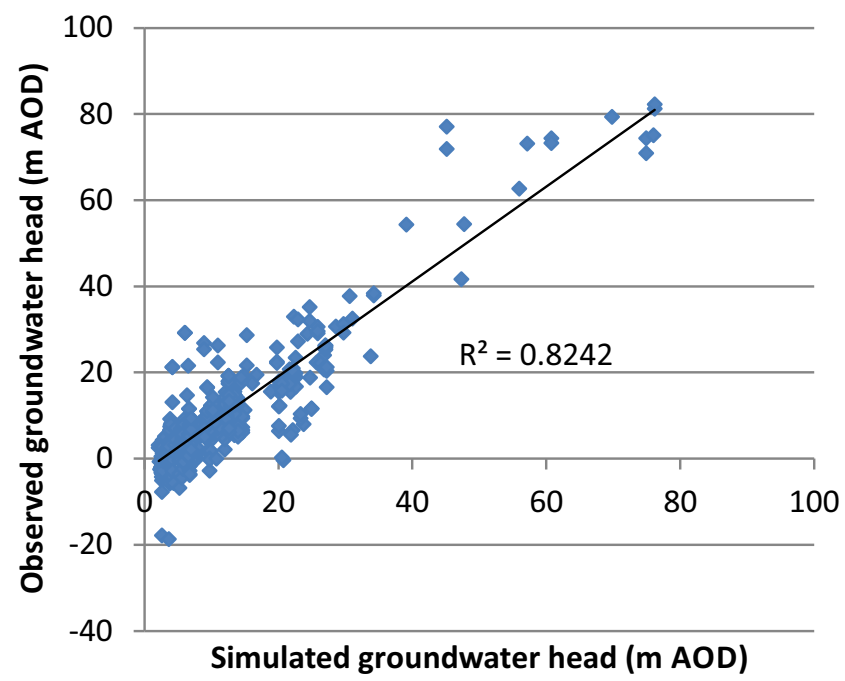

Fig. 9 Q-Q plot comparing the simulated and observed groundwater heads over the Clyde Valley 
Table 3 Model aquifer hydraulic parameters after calibration process

\begin{tabular}{lll}
\hline Hydrogeological unit & Parameter value & Units \\
\hline Clyde Valley and Proto-Kelvin Valley Quaternary aquifers & 100 & $\mathrm{~m} \mathrm{day}^{-1}$ \\
Till (non aquifer) & 0.1 & $\mathrm{~m}_{\text {day }}{ }^{-1}$ \\
Carboniferous sedimentary bedrock & 1 & $\mathrm{~m} \mathrm{day}^{-1}$ \\
Vertical conductance (Quaternary aquifer) & 0.01 & $\mathrm{~m}^{2}$ day $^{-1}$ \\
Vertical conductance (till) & 10 & $\mathrm{~m}^{2}$ day $^{-1}$ \\
Riverbed conductance & 10 & $\mathrm{~m}^{2}$ day $^{-1}$ \\
\hline
\end{tabular}

The simulated groundwater heads indicate that regional movement of groundwater is from the areas of high ground in the south and east of Glasgow towards the River Clyde, which is in agreement with previous assertions about regional groundwater flow (e.g. Robins, 1990). The model also indicates the down-valley flow of groundwater within the Quaternary Clyde Valley Aquifer which was suggested more recently (Bonsor et al. 2010).

The model indicates that groundwater flow in the bedrock converges from the north and east of the study area into the Cadder Sand and Gravel Formation in the Proto-Kelvin Valley Aquifer, through which it moves towards the River Clyde. However, because there are no observed groundwaterlevel data for the Proto-Kelvin Valley Aquifer, these results cannot yet be validated. By contrast, the modelled groundwater levels in the Clyde Valley Aquifer give clear indications of groundwater interaction with the River Clyde, with groundwater discharging from the Quaternary valley aquifer to the river, as supported by the limited available observed groundwater level data.

In the west of the study area, the model shows steep groundwater gradients as groundwater flows from high ground either towards various tributary rivers or directly towards the Clyde Valley Aquifer, eventually discharging into the River Clyde. There are no observed groundwater level data in this area, and so these results cannot yet be verified.

\section{Discussion and conclusions}

The results from numerical modelling indicate that the general direction of groundwater flow in Glasgow is downgradient from areas of high ground towards the lowland valleys and ultimately the River Clyde, through both bedrock and Quaternary potential aquifers. Groundwater levels in the modelled Quaternary Clyde Valley Aquifer are strongly influenced by the course of the River Clyde and its major tributaries. There is an indication of hydraulic connection between groundwater within the Clyde Valley Aquifer and the River Clyde, and there is also flow down-valley, parallel to the River Clyde, within this hydrogeological unit. In the Proto-Kelvin Valley Aquifer, within a major buried (or tunnel) valley incised deeply in bedrock, groundwater appears to flow down-valley towards the River Clyde, but there are no large rivers over much of this aquifer and no significant groundwater-river interaction.

In the west of the model area, closely spaced groundwater contours reflect steep gradients as groundwater flows from high ground towards a series of tributaries in this area. However, this region is least constrained by groundwater level data, and model results for this area are, therefore, least reliable. Because the modelled riverbed elevations were estimated crudely from available DTMs, this could result in erroneously high modelled groundwater gradients.

The model suggests that Quaternary deposits in the Proto-Kelvin Valley (dominated by the Cadder Sand and Gravel Formation) constitute a significant aquifer, accepting and transporting groundwater towards the River Clyde. However, no groundwater data for this region are available and it is not possible, therefore, to validate the modelled groundwater behaviour. Additional groundwater data would be required for the Cadder Sand and Gravel Formation, particularly for the area where it converges with the River Clyde and particularly focused on vertical gradients at discrete depths, to confirm whether the model presents a true representation of groundwater behaviour in this region.

Most groundwater data used to develop the model are for central and eastern Glasgow, within the Clyde Valley Aquifer, and it is here that one can draw the most robust conclusions about the validity of the model results. Agreement between observed and simulated heads is generally within $2-5 \mathrm{~m}$, less than $5 \%$ of the total range in groundwater level across the study area. The model indicates groundwater moves down gradient within the valley hydrogeological units and also shows significant interaction with the surface waters of the River Clyde, both of which confirm conclusions from previous work.

The refined conceptual model for the Quaternary groundwater system in Glasgow set out in this report has been broadly validated by the numerical modelling exercise also presented here. The Gourock and Bridgeton Sand members act as a highly conductive shallow aquifer in the Clyde Valley, and function in the regional transport of shallow groundwater, which appears to show significant interaction with the River Clyde. The Cadder Sand and Gravel Formation appears to be a potentially significant aquifer, but validated conclusions about groundwater behaviour within it are not possible at this time given available data. The underlying Carboniferous sedimentary bedrock is able to transport recharge from areas of high ground down gradient towards the two Quaternary valley aquifers, though more work would be needed to confirm the extent to which the bedrock receives recharge through thin and/or patchy till deposits on higher ground.

Three-dimensional geological models cover almost the entire groundwater model area, but to the west they are based on very few borehole data. The improvement of these 3D geological models to the west would improve the geological representation and consequent hydrogeological 
understanding in this region. Nevertheless, this work still demonstrates the importance of the information acquired from 3D geological models to improve our conceptual hydrogeological understanding.

Recharge estimates could be improved by sourcing more accurate estimates of piped water leakage losses from both the sewer and pressurised water main network within the urban area. River flow gauging at the eastern end of the River Clyde within the study area would be advantageous in constraining the flow volumes within the modelled river and thus provide a more accurate simulation of the groundwater regime.

Long-term groundwater monitoring data would be required to show the behaviour of the groundwater system over time. A prototype network is being established by the British Geological Survey, the Glasgow City Council, and the Scottish Environment Protection Agency (SEPA), but few monitoring locations have been established so far, and few data are yet available. Further efforts to constrain the hydrogeological parameters of the various geological units, including riverbed deposits, which could include targeted test pumping, could improve understanding of the system, but they also depend upon improved groundwater level data availability and spatial distribution in order for their impact to be maximised.

As well as validating the refined conceptual groundwater model, the numerical model provides an opportunity to simulate possible future scenarios and investigate particular urban development issues in Glasgow. For example, the numerical model allows the study of the impact of proposed engineering structures on the groundwater levels and flows. It could also assist the understanding of remediation of contaminated land through the simulation of the transport of pollutants. The numerical model can be also used in Glasgow for the mitigation of urban flooding and studying the potential impacts of the installation of sustainable drainage systems (SuDS) on groundwater levels across the city.

Acknowledgements This work was supported by the International Resources and Recycling Institute Funded by INTERREG IVC for Sustainable Hydro Assessment and Groundwater Recharge Projects (SHARP, http://www.sharp-water.eu/). The report is published by permission of the Executive Director of the British Geological Survey (Natural Environment Research Council).

Open Access This article is distributed under the terms of the Creative Commons Attribution License which permits any use, distribution, and reproduction in any medium, provided the original author(s) and the source are credited.

\section{References}

Artimo A, Makinen J, Berg RC, Abert CC, Salonen VP (2003) Three-dimensional geologic modelling and visualisation of the Virttaankangas, southwestern Finland. Hydrogeol J 11:378-386

Ball D, Graham M, Ó Dochartaigh BÉ, Irving K, Simpson E (2006) Scottish aquifer properties: 2006 interim report. CR/06/073N, British Geological Survey, Keyworth, UK. http:// nora.nerc.ac.uk/7448/. Accessed September 2014
Berg RC, Mathers SJ, Kessler H, Keefer DA (eds) (2011) Synopsis of current three-dimensional geological mapping and modeling in geological survey organizations. Illinois State Geol Surv Circ $578,92 \mathrm{pp}$

Bonsor HC, Bricker SH, Ó Dochartaigh BÉ, Lawrie KIG (2010) Project progress report 2010-11: groundwater monitoring in urban areas - a pilot study in Glasgow, UK. British Geological Survey internal report IR/10/087, BGS, Keyworth, UK. http:// nora.nerc.ac.uk/15773/. Accessed September 2014

Burke HF, Morgan DJ, Kessler H, Cooper AH (2010) A 3D geological model of the superficial deposits of the Holderness area. British Geological Survey commissioned report CR/09/ 132, BGS, Keyworth, UK

Campbell SDG, Merritt JE, Ó Dochartaigh BÉ, Mansour MM, Hughes AG, Fordyce FM, Entwisle DC, Monaghan AA, Loughlin SC (2010) 3D geological models and their hydrogeological applications: supporting urban development - a case study in Glasgow-Clyde, UK. Z Dtsch Ges Geowiss 161(2):251-262. doi:10.1127/1860-1804/2010/0161-0251

Cherry D, Gill B, Pack T, Rawling T (2011) Geoscience Australia and GeoScience Victoria: 3-D geological modeling developments in Australia. In: Berg RC, Mathers SJ, Kessler H, Keefer DA (eds) Synopsis of current three-dimensional geological mapping and modeling in geological survey organizations, chapter 5. Illinois State Geol Surv Circ 578, 92 pp

Cuthbert MO, Mackay R, Tellam JH, Thatcher KE (2010) Combining unsaturated and saturated hydraulic observations to understand and estimate groundwater recharge through glacial till. J Hydrol 391(3-4):263-276. doi:10.1016/ j.jhydrol.2010.07.025

Epting J, Huggenberger P, Rauber M (2008) Integrated methods and scenario development for urban groundwater management and protection during tunnel road construction: a case study of urban hydrogeology in the city of Basel, Switzerland. Hydrogeol J 16:575-591

Gobel P, Stubbe H, Weinert M, Zimmerman J, Fach S, Dierkes C, Kories H, Messer J, Mertsch V, Geiger W, Coldewey W (2004) Near-natural stormwater management and its effects on the water budget and groundwater surface in urban areas taking account of the hydrogeological conditions. J Hydrol 299:267283

Grindley J (1967) The estimation of soil moisture deficits. Meteorol Mag 96:97-108

Hall IHS, Browne MAE, Forsyth IH (1998) Geology of the Glasgow district: memoir for 1:50,000 geological sheet 30E (Scotland). British Geological Survey, Keyworth, UK

Heathcote JA, Lewis RT, Sutton JS (2004) Groundwater modelling for the Cardiff Bay Barrage, UK: prediction, implementation of engineering works and validation of modelling. Q J Eng Geol Hydrogeol 36:159-172

Hughes AG, Mansour MM, Robins NS (2008) Evaluation of distributed recharge in an upland semi-arid karst system: the West Bank Mountain Aquifer. Hydrogeol J. doi:10.1007/ s10040-008-0273-6

Jackson CR (2004) User's manual for the particle tracking model ZOOPT. Internal report IR/04/141, British Geological Survey, Keyworth, UK, 46 pp. http://nora.nerc.ac.uk/12620/. Accessed September 2014

Jackson CR, Spink AEF (2004) User's manual for the groundwater flow model ZOOMQ3D. Internal report IR/04/140, British Geological Survey, Keyworth, UK. http://nora.nerc.ac.uk/ 11829\%. Accessed October 2014

Kessler H, Mathers S, Lelliott M, Hughes A, Macdonald D (2007) Rigorous 3D geological models as the basis for groundwater modelling. Annual meeting Geological Society of America, Denver CO, 27 Oct 2007

Kessler H, Mathers SJ, Sobisch HG (2009) The capture and dissemination of integrated 3D geospatial knowledge at the British Geological Survey using GSI3D software and methodology. Comput Geosci 35:1311-1321. doi:10.1016/ j.cageo.2008.04.005

Lerner DN (2002) Identifying and quantifying urban recharge: a review. Hydrogeol J 10:143-152 
Mansour MM, Hughes A, Ó Dochartaigh BÉ, Graham M (2008) Representation of urban recharge processes in the distributed recharge model (ZOODRM) of the Glasgow urban area, Scotland. In: MODFLOW and More 2008: ground water and public policy. Golden, CO, 19-21 May 2008

Mansour MM, Barkwith A, Hughes A (2011) A simple overland flow calculation method for distributed groundwater recharge models. Hydrol Process. doi:10.1002/hyp.8074

Martin PJ, Frind EO (1998) Modelling a complex multi-aquifer system: the Waterloo Moraine. Ground Water 36(4):679-690

Merritt JE, Monaghan AA, Loughlin SC, Mansour MM, Ó Dochartaigh BÉ, Hughes AG (2009) Clyde Gateway pilot 3D geological and groundwater model. British Geological Survey commissioned report CR/09/005, BGS, Keyworth, UK

Met Office (2014) Springburn (Nearest climate station to Glasgow). Climate period: 1981-2010. http://www.metoffice.gov.uk/public/weather/climate/gcuvz1zbv. Accessed October 2014

Monaghan AA, Arkley SLB, Whitbread K, McCormac M (2014) Clyde superficial deposits and bedrock models released to the ASK Network 2014: a guide for users. Version 3. British Geological Survey open report OR/14/013, BGS, Keyworth, UK. http://nora.nerc.ac.uk/505554/. Accessed October 2014

Morris DG, Flavin RW (1990) A digital terrain model for hydrology. In: Proceedings of the 4th International Symposium on Spatial Data Handling, vol 1. Zurich, 23-27 July 1990, pp $250-262$

Natural Environment Research Council (NERC) (2003) Hydrological data United Kingdom, hydrometric register and statistics 1996-2000. Centre for Ecology and Hydrology, Wallingford, UK

Ó Dochartaigh BÉ (2005) Review of hydrogeological knowledge of the Clyde Basin. Internal report IR/05/079, British Geological Survey, Keyworth, UK, 21 pp. http://nora.nerc.ac.uk/11120/. October 2014

Penman HL (1948) Natural evaporation from open water, bare soil and grass. Proc R Soc Lond A 193:120-145

Robins NS (1990) Hydrogeology of Scotland. HMSO for British Geological Survey, London

Robins NS, Rutter HK, Dumpleton S, Peach DW (2005) The role of $3 \mathrm{D}$ visualisation as an analytical tool preparatory to numerical modelling. J Hydrol 301:287-295
Royse KR, Kessler H, Robins NS, Hughes AG, Mathers SJ (2010) The use of 3D geological models in the development of the conceptual groundwater model. Z Dtsch Ges Geowiss 161(2):237-249. doi:10.1127/1860-1804/2010/0161-0237

Russell HAJ, Boisvert E, Logan C, Paradis SJ, Ross M, Sharpe DR, Smirnoff A (2011a) Three-dimensional geological mapping for groundwater applications. In: Berg RC, Mathers SJ, Kessler H, Keefer DA (eds) Synopsis of current three-dimensional geological mapping and modeling in geological survey organizations, chapter 7. Illinois State Geol Surv Circul 578, 92 pp

Russell HAJ, Rivera A, Wang S, Sharpe DR (2011b) From atmosphere to basement: development of a framework for groundwater assessment in Canada. Three-dimensional geological mapping, workshop extended abstracts, Dossier public 6998, Commission géologique du Canada, Quebec City

Sharpe DR, Barnett JP, Russell HAJ, Brennand TA, Gorrell G (1999) Regional geological mapping of the Oak Ridges Moraine, greater Toronto Area, southern Ontario. In: Current research 1999-E, Geological Survey of Canada, Ottawa, pp 123-136

Spottke I, Zechner E, Huggenberger P (2005) The southeastern border of the Upper Rhine Graben: a 3D geological model and its importance for tectonics and groundwater flow. Int $\mathrm{J}$ Earth Sci 94:580-593

Thomsen R (2011) 3D groundwater mapping in Denmark based on calibrated high-resolution airborne geophysical data. Threedimensional geological mapping, workshop extended abstracts, Dossier public 6998, Commission géologique du Canada, Quebec City

White PA, Tschritter C, Davidson P (2013) Development of threedimensional models of sedimentary lithologies and piezometric levels to understand groundwater and surface water flows, Lower Wairau Plain, Marlborough, New Zealand with web and smartphone access to model data. In: Thorleifson LH, Berg RC, Russell HAJ (2013) Three-dimensional geological mapping: workshop extended abstracts. Geological Society of America Annual Meeting, Denver, CO, 26 October 2013, Minnesota Geol Surv Open File Rep OFR-13-2, 84 pp

Wycisk P, Hubert T, Gossel W, Neumann CH (2009) Highresolution $3 \mathrm{D}$ spatial modelling of complex geological structures for an environmental risk assessment of abundant mining and industrial megasites. Comput Geosci 35:165-182 